\title{
EUGENE O’NEILl'S
}

Creative Struggle 
Also by Doris Alexander

Creating Characters with Charles Dickens

The Tempering of Eugene O'Neill 


\section{DORIS AlEXANDER}

\section{EugENE O’NEILL'S \\ Creative Struggle}

The Decisive Decade, 1924-1933 
Quotations from the following plays are reprinted from The Plays of Eugene O'Neill, by permission of Random House, Inc., New York, and Jonathan Cape Limited, London:

Marco Millions, Copyright 1927 and renewed 1955 by Carlotta Monterey O'Neill; The Great God Brown, Copyright 1926 and renewed 1954 by Carlotta Monterey O'Neill; Lazarus Laughed, Copyright 1926, 1927 and renewed 1954, 1955 by Eugene O'Neill and Carlotta Monterey O'Neill; Strange Interlude, Copyright 1928 and renewed 1956 by Carlotta Monterey O'Neill; A $h$, Wilderness!, Copyright 1933 by Eugene O'Neill and renewed 1961 by Carlotta Monterey O'Neill; Desire Under the Elms, Copyright 1924 and renewed 1952 by Eugene O'Neill; Mourning Becomes Electra, Copyright 1931 and renewed 1959 by Carlotta Monterey O'Neill; Dynamo, Copyright 1929 and renewed 1957 by Carlotta Monterey O'Neill; Days Without End, Copyright 1934 by Eugene O'Neill and renewed 1962 by Carlotta Monterey O'Neill.

Library of Congress Cataloging-in-Publication Data

Alexander, Doris.

Eugene O'Neill's creative struggle : the decisive decade, 1924-1933 / Doris Alexander.

p. $\mathrm{cm}$.

Includes index.

ISBN 0-271-00813-X

1. O'Neill, Eugene, 1888-1953. 2. Dramatists, American-20th century-Biography. I. Title.

PS3529.N5Z555 1992

$812^{\prime} .52-\mathrm{dc} 20$

[B]

91-29976

CIP

Copyright (C) 1992 Doris Alexander

All rights reserved

It is the policy of The Pennsylvania State University Press to use acid-free paper for the first printing of all clothbound books. Publications on uncoated stock satisfy the minimum requirements of American National Standard for Information Sciences-Permanence of Paper for Printed Library Materials, ANSI Z39.48-1984. 